\title{
Pelatihan Pembuatan Media Pembelajaran Interaktif Berbasis Macromedia Flash untuk Guru-guru di SMA Perintis 1 Bandar Lampung
}

\author{
Henry Kurniawan*, Eko Subyantoro, Tri Sandhika Jaya
}

Program Studi D-3 Manajemen Informatika, Politeknik Negeri Lampung November, Indonesia

\begin{abstract}
The Role of Human Resources is needed to adopt all the changes that occur. Human resources in schools must always be developed continuously to improve the ability to be in accordance with the demands of the educational environment. One way to improve teachers' skills and expertise is education and training. The training conducted at Bandar Lampung's Perintis 1 High School was aimed at teachers to improve their skills, knowledge and attitudes in order to improve current and future performance in developing students' processes, resources, and maturity in learning media by using computer software in the form of macromedia flash.This dedication resulted in an increase in teachers' knowledge and skills in making interactive learning media for macromedia flash programs, as seen from 29 teachers (67\%) who did not introduce PBK software to all teachers (100\%) knew the PBK (Computer Assisted Learning) software. Then from 8 teachers $(0.186 \%)$ who already knew and used the macromedia flash program, all teachers knew and used this program. This can be seen in the initial demonstration that only 10 teachers were able to run the program. While progress and understanding with the use of macromedia flash, only 2 teachers who are able to run and understand macromedia flash make all teachers able to run and understand this program. The level of desire to make and use the macromedia program also increased by 8 teachers (18.6\%) to 40 people (93\%). Through this training activity, products were obtained in the form of macromedia flash learning CDs that can be used to achieve learning goals and create an interesting learning atmosphere.
\end{abstract}

Keywords: Teacher, student, macromedia flash, interest in learning, learning outcomes.

\section{ABSTRAK}

Peran Sumber Daya Manusia sangat diperlukan untuk menanggani segala perubahan yang terjadi. Sumber Daya Manusia yang ada di sekolah harus selalu dikembangkan secara kontinyu guna meningkatkan kemampuan agar sesuai dengan tuntutan lingkungan pendidikan. Salah satu cara untuk meningkatkan kemampuan dan keahlian guru yaitu dengan pendidikan dan pelatihan. Pelatihan yang dilakukan di SMA Perintis 1 Bandar Lampung ini ditujukan kepada guru-guru untuk meningkatkan keahlian, pengetahuan, dan sikap dalam rangka meningkatkan kinerja saat ini dan masa yang akan datang pada pengembangan proses, sumber, dan kematangan siswa pada media pembelajaran dengan memanfaatkan software computer berupa macromedia flash. Pengabdian ini menghasilkan peningkatan pengetahuan dan keterampilan guru dalam pembuatan media pembelajaran interaktif program macromedia flash yang terlihat dari 29 orang guru (67\%) yang belum mengenalkan software PBK menjadi semua guru (100\%) mengenal software PBK (Pembelajaran Berbantuan Komputer). Kemudian dari 8 orang guru $(0,186 \%)$ yang sudah mengenal dan menggunakan program macromedia flash menjadi semua guru

${ }^{*}$ Corresponding author:

Henry Kurniawan

Program Studi D-3 Manajemen Informatika, Politeknik Negeri Lampung November, Indonesia

Email: henry_stk@polinela.ac.id
How to cite:

Pelatihan Pembuatan Media Pembelajaran Interaktif Berbasis Macromedia Flash untuk Guru-guru di SMA Perintis 1 Bandar Lampung. B. J. Pengabdian. Masyarakat. Indonesia. 1 (1): 11 20. 
mengenal dan menggunakan program ini. Hal ini terlihat pada demonstrasi awal hanya 10 orang guru yang mampu menjalankan program tersebut. Sedangkan kemajuan serta paham dengan penggunaan macromedia flash pun hanya 2 orang guru saja yang mampu menjalankan dan paham dengan macromedia flash ini menjadikan semua guru mampu menjalankan dan paham dengan program ini. Tingkat keinginan membuat dan menggunakan program macromedia pun meningkat 8 orang guru (18,6\%) menjadi 40 orang (93\%). Melalui kegiatan pelatihan ini, diperoleh produk berupa CD pembelajaran berbasis macromedia flash yang dapat digunakan untuk mencapai tujuan pembelajaran dan menciptakan suasana pembelajaran yang menarik.

Kata kunci: Guru, siswa, macromedia flash, minat belajar, hasil belajar

\section{PENDAHULUAN}

\section{Analisis Situasi}

Peran Sumber Daya Manusia sangat diperlukan untuk menanggani segala perubahan yang terjadi. Sumber Daya Manusia yang ada di sekolah harus selalu dikembangkan secara kontinyu guna meningkatkan kemampuan agar sesuai dengan tuntutan lingkungan pendidikan. Salah satu cara untuk meningkatkan kemampuan dan keahlian guru yaitu dengan pendidikan dan pelatihan.

Pelatihan merupakan aktivitas yang dilakukan untuk meningkatkan keahlian, pengetahuan, dan sikap dalam rangka meningkatkan kinerja saat ini dan masa yang akan datang. Menurut Tziner, et al, [1] yang menjadi dasar tujuan pelatihan adalah membantu orang mengembangkan keahlian dan kemampuannya, ketika menerapkan ke pekerjaan, akan dapat meningkatkan kinerja mereka. Definisi lain mengatakan bahwa pelatihan adalah sebuah perencanaan pengalaman belajar yang di desain untuk membawa perubahan pada pengetahuan, kemampuan, atau keahlian individu [2]. Oleh karena itu pelatihan merupakan suatu kegiatan yang sangat diperlukan bagi setiap organisasi terutama dalam menghadapi perubahan-perubahan lingkungan yang cepat terjadi. Melalui pelatihan, diharapkan guru akan berkembang dengan baik sehingga mampu menghadapi tantangan perubahan [3].

Pentingnya pelatihan untuk pengembangan individu tentunya memerlukan investasi yang tidak sedikit, dan hasil dari pelatihan sering tidak langsung terlihat, maka pihak sekolah dalam memberikan pelatihan harus secara terencana dan menyesuaikan dengan pekerjaan sehingga hasil dari pelatihan tersebut dapat mengubah perilaku guru di tempat kerja [4.5]. Oleh karena itu evaluasi terhadap pelatihan yang telah dilaksanakan sangat diperlukan untuk mengetahui keefektifan pelatihan itu sendiri pada pekerjaan.

Salah satu pelatihan guru dalam meningkatkan kemampuan dan keahlian nya adalah pelatihan pembuatan media pembelajaran interaktif berbasis komput- er di sekolah untuk meningkatkan motivasi belajar siswa dan hasil belajar siswa pada proses kegiatan belajar mengajar.

Hasil observasi yang dilakukan berkaitan dengan kemampuan dan keahlian guru di SMA Perintis 1 Bandar Lampung pada proses kegiatan belajar mengajar ada dua hal, yaitu [6]:

1. Pertama, dari pihak siswa sendiri ketika penulis bertanya kepada guru misalnya, rendahnya partisipasi aktif siswa dalam mengikuti pembelajaran, sehingga proses kegiatan belajar mengajar hanya berjalan satu arah dari guru. Siswa kurang berkonsentrasi dalam proses belajarnya sehingga mengganggu penerimaan pelajaran yang disampaikan oleh guru, akibatnya prestasi siswa menurun.

2. Kedua, dari pihak guru ketika penulis bertanya kepada siswa, bahwa penjelasan yang dilakukan oleh guru kurang menarik dan kurang jelas, sehingga siswa menjadi bingung, media yang digunakan kurang menarik, dalam menerangkan guru hanya menuliskan pokok bahasan yang pentingpenting saja dan tulisannya kurang jelas sehingga siswa kesulitan dalam membuat catatan.

Berangkat dari permasalahan $\mathrm{di}$ atas, penulis kemudian melakukan diskusi dengan guru pengampu mata pelajaran yang bersangkutan. Dalam diskusi tersebut guru memberikan saran untuk menggunakan media berbasis komputer dalam proses belajar mengajar [7]. Media pembelajaran yang dipilih dibuat dengan software macromedia flash yang belum banyak digunakan oleh para guru di SMA Perintis 1. Berdasarkan diskusi yang telah dilakukan kemudian disepakati melakukan pengabdian berupa pelatihan guru menggunakan media pembelajaran interaktif berbasis software macromedia flash [8]. Dengan bantuan media ini diharapkan siswa akan 
lebih mudah untuk memahami materi pelajaran dan motivasi belajar siswa akan meningkat, sehingga berdampak positif terhadap prestasi belajar siswa. Media yang digunakan adalah media yang sudah teruji validitasnya.

\section{Identifikasi dan Perumusan Masalah}

Permasalahan yang dihadapi oleh guru saat ini adalah belum mampu menyediakan media pembelajaran yang lebih menarik agar hasil belajar siswa meningkat. Hal tersebut menyebabkan pemahaman siswa pada materi yang diajarkan cenderung rendah karena penyampaian materi pembelajaran kurang menarik. Selain itu juga terjadi kurangnya komunikasi antara guru dengan siswanya dalam saat proses belajar dari awal penyampaian materi sampai berakhir.

\section{Kerangka Pemecahan Masalah}

Berdasarkan identifikasi masalah pada penyelenggaraan kegiatan belajar mengajar maka permasalahan utama yang dihadapi adalah minimnya pengetahuan membuat media pembelajaran interaktif oleh guru, dan kurangnya pemanfaatan teknologi modern yang sangat menunjang suksesnya proses pembelajaran berbasis teknologi komputer. Berdasarkan permasalahan yang ada maka upaya yang perlu dilakukan adalah meningkatkan kemampuan SDM guru melalui pelatihan pembuatan media pembelajaran interaktif berbasis macromedia flash agar tujuan yang ingin dicapai pada proses kegiatan belajar mengajar sesuai dengan yang diharapkan.

Pada saat pelatihan seorang trainer harus memastikan bahwa seorang guru dapat secara efektif menggunakan teknologi-teknologi baru yang telah dipelajari. Perubahan teknologi, pada gilirannya, berarti bahwa pekerjaan-pekerjaan sering berubah dan keahlian serta kemampuan guru mestilah dimuktakhirkan melalui pelatihan sehingga kemajuan teknologi tersebut secara sukses dapat diintegrasikan ke dalam sekolah.

Berdasarkan uraian tersebut, kerangka pemecahan masalah yang diajukan dapat dilihat pada Gambar 1.

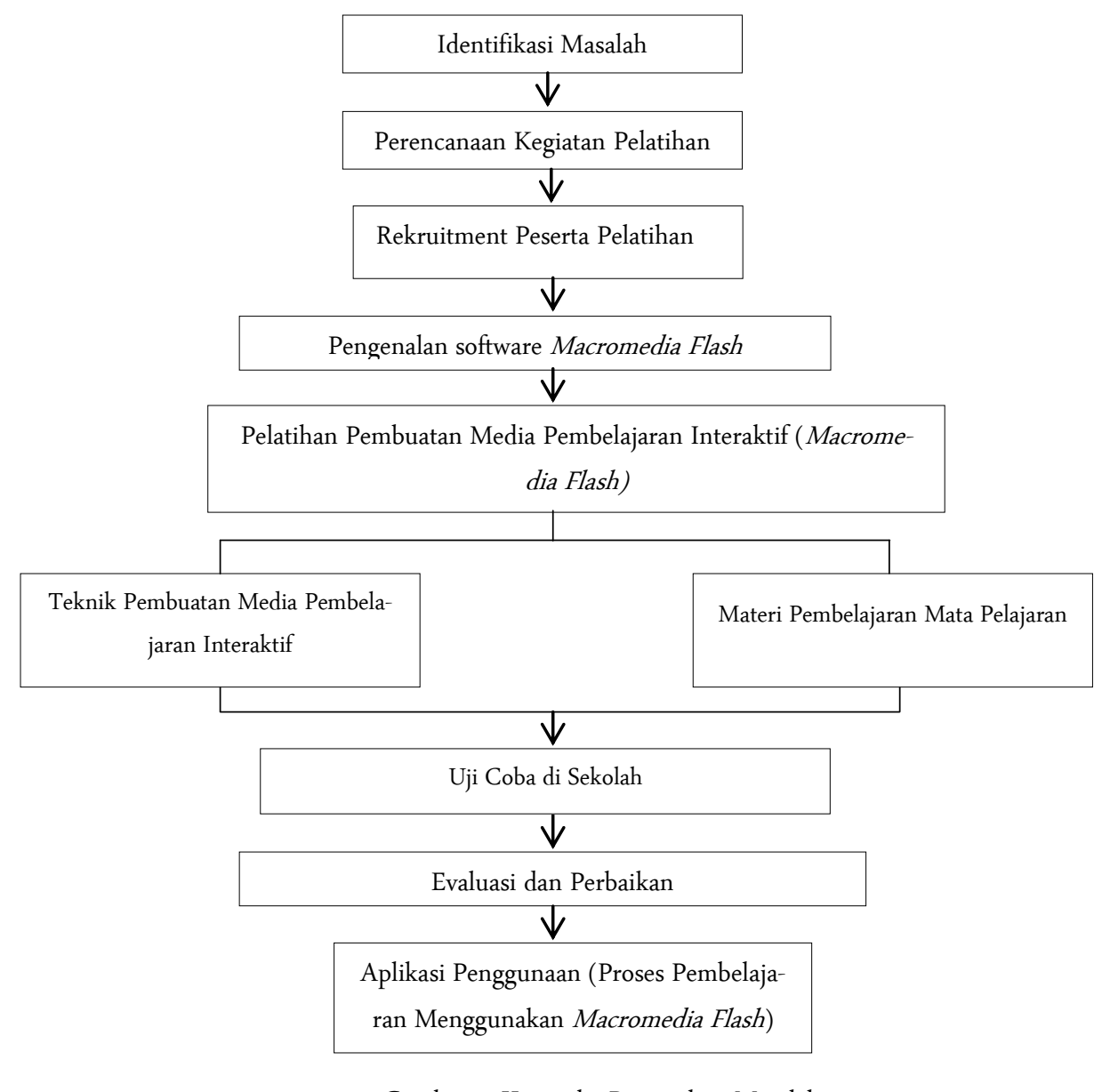

Gambar 1. Kerangka Pemecahan Masalah 


\section{Tujuan Kegiatan}

Tujuan kegiatan pelatihan pembuatan media pembelajaran interaktif berbasis macromedia flash untuk guru-guru di SMA Perintis 1 Bandar Lampung ini adalah:

1. Meningkatkan pengetahuan guru tentang macromedia flash.

2. Meningkatkan keterampilan guru dalam membuat media pembelajaran interaktif berbasis macromedia flash

3. Mengaplikasikan penggunaan macromedia flash pada proses kegiatan belajar mengajar

\section{Manfaat Kegiatan}

Manfaat dari kegiatan pelatihan pembuatan media pembelajaran interaktif berbasis macromedia flash untuk guru-guru di SMA Perintis 1 Bandar Lampung ini adalah :

1. Meningkatkan kualitas guru pada proses kegiatan belajar mengajar sehingga mampu mencapai output dan standar kualitas yang diharapkan.

2. terjalinnya kerja sama dalam proses belajar mengajar antara siswa dan guru.

3. Meningkatkan kinerja guru pada saat ini dan masa yang akan datang.

4. Perubahan pola perilaku guru yang spesifik berkaitan dengan pekerjaan, sehingga mendorong mereka untuk dapat bekerja lebih baik.

5. Memutakhirkan keahlian para guru sejalan dengan kemajuan teknologi.

6. Sebagai media untuk melaksanakan tridarma perguruan tinggi khususnya di bidang pengabdian, dan sebagai sarana untuk mentransfer ilmu pengetahuan yang bermanfaat bagi masyarakat.

\section{MATERI DAN METODE}

\section{Kajian Pustaka: Pengenalan Macromedia Flash}

Macromedia Flash adalah software yang banyak dipakai oleh desainer web karena mempunyai kemampuan yang lebih unggul dalam menampilkan multimedia, gabungan antara grafis, animasi, suara, serta interaktifitas user. Macromedia Flash merupakan sebuah program aplikasi standar authoring tool profesional yang digunakan untuk membuat animasi vektor dan bitmap yang sangat menakjubkan untuk membuat suatu situs web yang interaktif, menarik dan dinamis.
Software ini berbasis animasi vektor yang dapat digunakan untuk menghasilkan animasi web, presentasi, game, film, maupun CD interaktif, CD pembelajaran [9].

Interaksi user dalam movie flash menggunakan Actionscript. Actionscript adalah suatu bahasa pemrograman yang berorientasi objek yang dipakai dalam Macromedia Flash, baik Flash MX maupun Flash versi sebelumnya. Macromedia Flash MX menyediakan fasilitas-fasilitas yang lebih banyak dan menarik yang akan membantu, mempermudah user dalam mempelajari atau menggunakan software ini dibandingkan dengan Flash versi sebelumnya. Animasi-animasi dapat dibuat dengan lebih sederhana, cepat dan lebih menarik menggunakan Flash MX karena adanya kelebihan yang dimiliki oleh Flash MX.

\section{Kajian Pustaka: Area Kerja Macromedia Flash}

Macromedia Flash MX mempunyai area kerja yang terdiri dari enam bagian pokok yaitu :

a. Menu

Berisi kumpulan instruksi atau perintah-perintah yang digunakan dalam Flash MX. Terdiri dari menu File, Edit, View, Insert, Modify, Text, Control, Window, Help.

b. Stage

Stage adalah layer (document dalam word) yang akan digunakan meletakkan objek-objek dalam Flash.

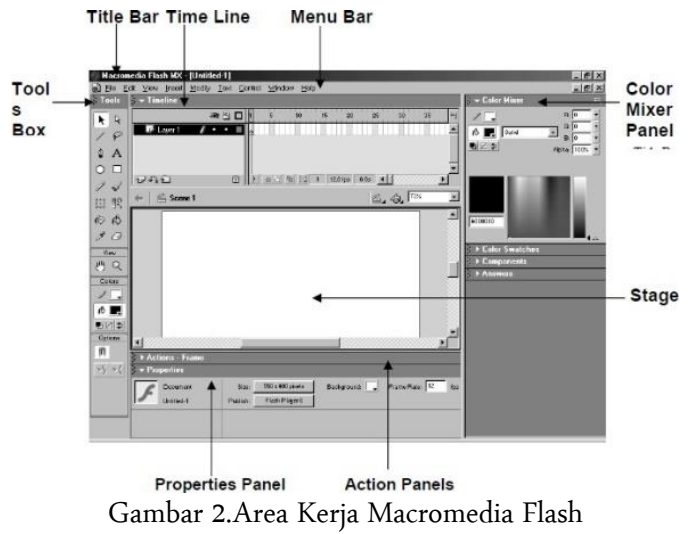

\section{Kajian Pustaka: Timeline}

Timeline berisi frame-frame yang berfungsi untuk mengontrol objek yang dibuat dalam stage atau layer yang akan dibuat animasinya.

\section{Kajian Pustaka: Toolbox}

Toolbox berisi tool-tool atau alat yang digunakan untuk membuat, menggambar, memilih, menulis, me- 
manipulasi objek atau isi yang terdapat dalam stage (layer) dan timeline. Alat-alat yang terdapat dalam toolbox adalah:

- Arrow tool : memilih dan memindahkan object.

- Subselect tool : memilih titik-titik pada suatu objek atau garis.

- Line tool : membuat garis

- Lasso tool : memilih sebagian dari object atau bagian tertentu dari object.

- Pen tool : menggambar garis-garis lurus maupun garis kurva.

- Text tool : menulis teks.

- Oval tool : membuat lingkaran.

- Rectange tool : membuat persegi maupun persegi panjang.

- Pencil tool : menggambar garis-garis bebas, seperti menggunakan pensil biasa.

- Brush tool : berfungsi seperti kuas untuk mengecat mewarnai suatu object

- Fill Transform tool : mengatur ukuran, tengah, arah dari warna gradasi atau bidang suatu objek

- Free Transform tool : mengubah dan memodifikasi bentuk dari objek yang dibuat bisa berupa memperbesar, memperkecil ukuran objek.

- Ink Bottle tool : menambah, memberi dan mengubah warna pada garis di pinggir suatu objek (Stroke).

- Paint bucket tool : menambah, memberi, mengubah warna pada bidang objek yang dibuat.

- Eyedropper tool : mengidentifikasikan warna atau garis dala suatu objek.

- Eraser tool : menghapus area yang tidak diinginkan dari suatu objek.

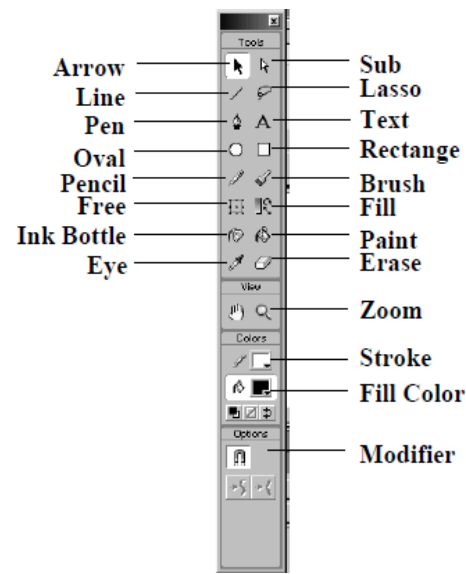

Gambar 3. Toolbox Macromedia Flash

\section{Kajian Pustaka: Objek Dalam Macromedia Flash}

Objek dalam Flash terbagi dalam dua unsur yaitu Fill objek dan stroke objek. Ketika menggambar objek dalam Flash seperti objek lingkaran, kotak, oval dll, secara otomatis Flash akan menyediakan dua unsur objek, yaitu Fill (bidang objek) dan Stroke (bingkai/pinggir objek) [10]. Untuk melakukan penyeleksian objek, dilakukan dengan menggunakan Arrow Tool yang terdapat dalam Tools Box, kemudian tinggal di klik fill atau stroke dari objekyang akan diseleksi. Untuk menyeleksi seluruh objek (fill dan stroke) double klik pada fill objek tersebut [11].

\section{Kajian Pustaka: Pengolahan Teks}

Teks digunakan untuk menerangkan atau menjelaskan sesuatu dalam bentuk tulisan, pembuatan judul, komponen animasi, keterangan-keterangan untuk movie interaktif. Teks merupakan bagian yang mempunyai perananl cukup besar dalam pembuatan animasi. Teks dapat dimanipulasi atau dimodifikasi seperti halnya objek dalam Flash MX sesuai dengan kebutuhan sehingga teks yang dihasilkan mempunyai banyak variasi [12].

Teks dalam Flash ditulis dengan memggunakan bantuan Text Tool pada Toolbox. Teks yang dihasilkan dapat di setting dengan menggunakan Propeties Panel. Propeties Panels untuk teks berisi menu atau atributatribut untuk membuat dan mengedit suatu teks. Flash MX mempunyai tiga tipe teks yang masing-masing mempunyai fungsi yang berbeda. Tipe teks tersebut adalah sebagai berikut:

1. Static Text adalah jenis teks yang mempunyai karakter-karakter seperti teks biasa pada umumnya.

2. Dynamic Text adalah jenis teks yang dapat menampilkan sifat teks yang dinamis dan bisa dikontrol, contohnya skor pertandingan olah raga yang yang dapat berganti sesuai dengan perolehan nilai dari pertandingan, nilai kurs mata uang dalam bursa efek, dll.

3. Input Text adalah jenis teks yang dapat diisi oleh pengguna atau user dalam sebuah form isian atau Input Text digunakan untuk menerima berbagai input dari user.

Teks yang ditulis atau dibuat dalam Flash orientasi dapat diubah sesuai dengan kebutuhan. Orientasi teks dalam flash ada tiga macam, yaitu :

1. Horizontal, digunakan untuk membuat teks yang mengalir dari kiri ke kanan secara 
horisontal seperti penulisan teks pada umumnya ( setting default).

2. Vertical Left-to-Right, digunakan untuk membuat teks yang mengalir ke bawah secara vertikal dari kiri ke kanan.

3. Vertical Right-to-Left, digunakan untuk membuat teks yang mengalir ke bawah dari kanan ke kiri.

\section{Tempat dan Waktu}

Kegiatan pelatihan pembuatan media pembelajaran interaktif berbasis Macromedia Flash untuk guru-guru dilakukan di SMA Perintis 1 Bandar Lampung yang berlangsung dalam jangka waktu 4 bulan sejak bulan Agustus sampai dengan November 2013.

\section{Khalayak Sasaran dan Cara Pelaksanaan}

Khalayak sasaran dalam pengabdian ini adalah guru-guru SMA Perintis 1 yang berlokasi di Jalan Cut Nyak Dien No. 4 Bandar Lampung. Jumlah guru tetap yayasan adalah 7 orang sedangkan jumlah guru tetap DPK adalah 7 orang dan jumlah guru tidak tetap adalah 41 orang. Sehingga sampai saat ini jumlah guru di SMA Perintis 1 adalah 55 orang.

Metode yang digunakan dalam pelatihan pembuatan media pembelajaran interaktif berbasis Macromedia Flash untuk guru-guru di SMA Perintis 1 Bandar Lampung ini adalah :

1. Melakukan survey awal dan menilai kelayakan pembuatan program.Tahap ini sebagai tahap studi kelayakan yang diperlukan untuk mengetahui memadai atau tidaknya sumberdaya yang dimiliki oleh guru-guru SMA Perintis 1 yang akan diberi pelatihan.

2. Mempelajari dan menganalisis media pembelajaran yang sedang berjalan.Tahap ini dilakukan untuk mengetahui sebab dan akibat yang ditimbulkan oleh sistem yang sedang berjalan.

3. Menentukan permintaan pengguna (Guru dan Siswa). Tahap ini untuk mengetahui keinginan/apa yang diharapkan oleh siswa dan guru pada proses kegiatan belajar mengajar. Secara umum keinginan para siswa dan guru meliputi menimbulkan kegirahan belajar, pengajaran lebih menarik perhatian siswa, metode mengajar lebih bervariasi, dan siswa lebih banyak beraktivitas pada proses kegiatan belajar mengajar. Pada tahap ini guru akan membantu dalam menentukan bagaimana sebaiknya proses kegiatan belajar mengajar harus berjalan sesuai dengan yang diharapkan.

4. Merancang program. Tahap ini adalah menterjemahkan keinginan siswa dan guru ke dalam bahasa komputer. Perancangan ini meliputi yaitu: input, output, bahasa yang digunakan, metode dan prosedur.

5. Menentukan hardware dan software komputer. Spesifikasi hardware yang dibutuhkan adalah minimal prosesor intel Pentium IV, RAM 128 MB, Hardisk 20 GB dan VGA Card $4 \mathrm{MB}$. Software yang dibuat adalah software macromedia flash mata pelajaran.

6. Membuat program (Macromedia Flash dari mata pelajaran). Tahap ini adalah tahap pembuatan program macromedia flash dari mata pelajaran yang telah disepakati.

7. Memperkenalkan program macromedia flash dari mata pelajaran. Program yang telah selesai dibuat, selanjutnya diperkenalkan untuk digunakan oleh guru pada proses kegiatan belajar mengajar.

8. Pelatihan pembuatan media pembelajaran interaktif. Pada tahap ini dilakukan pelatihan teknik pembuatan macromedia flash dan pengoperasian program baik secara tertulis maupun praktek. Sedangkan materi pembelajaran dari mata pelajaran yang akan dibuat dirancang sesuai dengan kebutuhan penggunaan program yang dibuat.

9. Melakukan evaluasi dan perbaikan untuk mengetahui penggunaan program yang telah dibuat. Kegiatan ini dilakukan dengan menyebarkan kuisioner yang berisi pertanyaan tentang informasi yang diperoleh dari hasil belajar maupun dari pengalaman secara langsung maupun tidak langsung meliputi: prinsip, metode, dan prosedur tentang penyampaian materi menggunakan macromedia flash.

\section{Rancangan Evaluasi Keberhasilan Program}

Secara garis besar evaluasi dibagi menjadi tiga jenis, yaitu evaluasi awal, evaluasi proses dan evaluasi akhir kegiatan.

1. Evaluasi awal dilakukan untuk mengetahui tingkat pengetahuan khalayak sasaran tentang penggunaan macromedia flash sebelum pelatihan dilakukan. Evaluasi awal menjadi dasar untuk menerapkan teknik dan pendeka- 
tan yang digunakan dalam proses pembuatan program.

2. Evaluasi proses akan diberikan sebanyak 2 kali dalam proses kegiatan. Evaluasi ini dilakukan dengan tujuan untuk mengetahui apakah materi yang disampaikan dapat dipahami atau tidak. Apabila peserta belum memahami materi dengan baik, maka akan diulang materi tersebut sampai dapat dipahami. Cara melakukan evaluasi ini adalah dengan uji pengetahuan dan keterampilan.

3. Evaluasi akhir dilakukan untuk mengevaluasi kegiatan secara keseluruhan dan dilakukan pada akhir program kegiatan. Caranya adalah dengan melakukan uji kemampuan dan keterampilan guru membuat media pembelajaran interaktif dengan memanfaatkan perangkat lunak macromedia flash. Di samping itu, juga akan dilakukan pemantauan khusus untuk berkelanjutan, pemantauan ini dilakukan 3 bulan setelah program selesai. Jika program ini tidak digunakan maka perlu dilakukan evaluasi penyebabnya.

Kriteria indikator kinerja yang akan digunakan sebagai tolok ukur pencapaian tujuan kegiatan tertera pada Tabel 1.

Tabel 1. Bibit tanaman herbal yang dikembangkan

\begin{tabular}{|c|c|c|c|c|}
\hline \multirow[b]{2}{*}{ Tahapan } & \multicolumn{3}{|c|}{ Indikator Kinerja } & \multirow[b]{2}{*}{ Dampak } \\
\hline & Indikator & $\begin{array}{l}\text { Awa } \\
1\end{array}$ & Akhir & \\
\hline $\begin{array}{l}\text { Pengenal } \\
\text { an ten- } \\
\text { tang } \\
\text { macro- } \\
\text { media } \\
\text { flash }\end{array}$ & $\begin{array}{l}\text { Tingkat } \\
\text { penge- } \\
\text { tahuan } \\
\text { guru ten- } \\
\text { tang mac- } \\
\text { romedia } \\
\text { flash }\end{array}$ & $<50$ & 100 & $\begin{array}{l}\text { Pema- } \\
\text { haman } \\
\text { guru ten- } \\
\text { tang mac- } \\
\text { romedia } \\
\text { flash }\end{array}$ \\
\hline $\begin{array}{l}\text { Demon- } \\
\text { trasi pro- } \\
\text { gram }\end{array}$ & $\begin{array}{l}\text { kemampu- } \\
\text { an guru } \\
\text { dalam } \\
\text { menjalan- } \\
\text { kan pro- } \\
\text { gram mac- } \\
\text { romedia } \\
\text { flash }\end{array}$ & $<30$ & 95 & $\begin{array}{l}\text { Kemam- } \\
\text { puan } \\
\text { dalam } \\
\text { men- } \\
\text { jalankan } \\
\text { program }\end{array}$ \\
\hline $\begin{array}{l}\text { Evaluasi } \\
\text { akhir } \\
\text { materi }\end{array}$ & $\begin{array}{l}\text { Kemajuan } \\
\text { dalam } \\
\text { pemaham- }\end{array}$ & $<50$ & 100 & $\begin{array}{l}\text { Kemu- } \\
\text { dahan } \\
\text { dalam }\end{array}$ \\
\hline
\end{tabular}

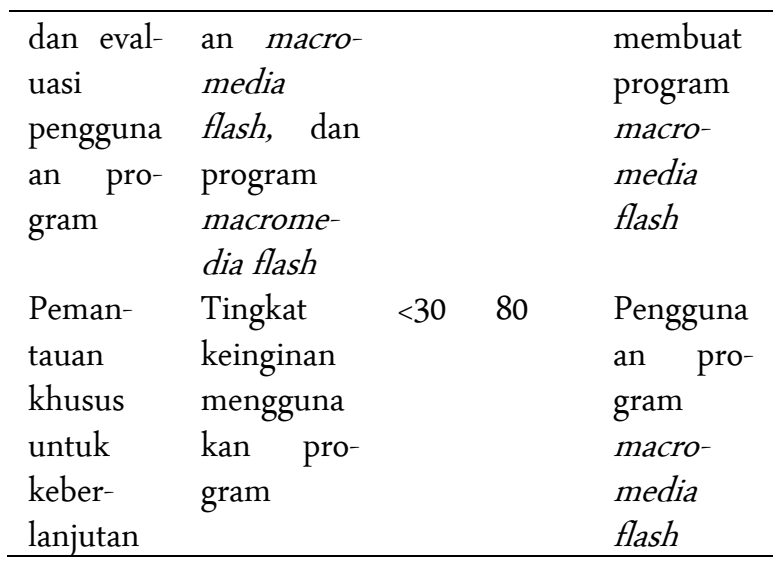

laju aliran air, model taherlarung, dan desain serta pembuatan prototipe fermenter pupuk organik. Tim teknis secara langsung melibatkan teknisi yang berpengalaman. Tim teknisi membuat prototipe teknologi cocok tanam aquaponik dan teherlarung yang sudah diotomatisasi dan mencobanya terlebih dahulu. Tim ini juga mendesain tempat kolam ikan dan modifikasinya.

Tim kedua adalah tim bibit yang bertugas untuk mempersiapkan jenis dan jumlah bibit tanaman TOGA. Tim ini melakukan survei dan studi banding ketempat-tempat pengembangan herbal yang sudah berkembang. Tim ini juga melakukan inventarisasi tanaman herbal yang ada di masyarakat. Tim bibit juga bertugas untuk pengadaan bibit ikan dan makanannya. Selain itu, tim ini juga bertugas untuk mempersiapkan starter untuk fermentasi limbah organik warga.

\section{Optimasi Kondisi Operasional Media Tanam Aqua- ponik}

Model media tanam aquaponik yang sudah jadi dioptimasi kondisi operasionalnya. Kondisi operasional yang dioptimasi diantaranya adalah laju aliran air, kemiringan pipa untuk aliran air, pencelupan tanaman dalam air, adaptasi ikan dan pemeliharaannya, dan optimasi tumbuh tanaman.

\section{Inventarisasi TOGA dan Tanaman Herbal di Masyara- kat}

Tim melibatkan warga untuk pengembangan TOGA di masyarakat. Pelibatan warga ini dilakukan dengan menginventarisasi tanaman herbal yang dimiliki warga. Selain itu juga ditanyakan penggunaan tanaman tersebut untuk mengobati penyakit dan alamat beserta no telpon warga. Hasil inventarisasi ini akan dijadikan dokumen inventaris tanaman herbal yang dimiliki warga di RT setempat dan akan dibagikan ke warga. 


\section{HASIL DAN PEMBASAHAN}

Pelatihan pembuatan media pembelajaran interaktif program macromedia flash terhadap guru di SMA Perintis 1 yang di mulai pelaksanaannya pada hari sabtu tanggal 21 September 2013 dan diikuti oleh 43 orang guru yang terdiri dari guru tetap yayasan adalah 2 orang sedangkan jumlah guru tetap DPK adalah 4 orang dan jumlah guru tidak tetap adalah 37 orang. Pada kegiatan ini sesi pertama berisi materi "Teknik Pengembangan Program Pembelajaran Berbasis Komputer (PBK)". Dari materi ini peserta memperoleh wawasan mengenai secara umum teknik pengembangan program pembelajaran berbasis komputer mulai dari perencanaal awal yang meliputi pengidentifikasian tujuan pembelajaran, kebutuhan belajar atau mengidentufikasi masalah-masalah dalam pembelajaran. Selanjutnya, menyiapkan materi untuk software pembelajaran berbasis komputer dengan mempertimbangkan dalam menyusun materi software PBK, berupa memilih materi yang sesuai untuk software PBK dan menentukan lingkup pembelajaran. Kemudian mendesain software pembelajaran berbasis komputer dengan menentukan desain software pmbelajaran berbasis komputer, menyusun materi software PBK yang akan diajarkan, sampai dengan menyusun dokumentasi/ petunjuk belajar.

Pada sesi diskusi tentang materi teknik pengembangan program pembelajaran berbasis komputer (PBK). Muncul pertanyaan dari peserta bahwa guruguru di sekolah peserta tersebut masih kurang memahami perbedaan antara model, materi dan software pembelajaran yang akan diterapkan. Kemudian pertanyaan selanjutnya adalah lingkup pembelajaran itu seperti apa dan bagaimana membuat desain yang akan dipilih oleh guru sehingga mudah diaplikasikan. Pertanyaan ini menunjukkan bahwa 29 guru (67\%) dari 43 guru SMA Perintis 1 kurang mendapatkan pengetahuan yang memadai mengenai perencanaan pembelajaran yang harus disusun oleh guru. Perencanaan yang dimaksud adalah penyusunan rencana pembelajaran yang baik sehingga diterapkan model, strategi, metode dan media pembelajaran yang tepat dan melibatkan siswa secara aktif pada aplikasi software komputer. Setelah diberikan materi semua peserta $(100 \%)$ paham dengan model, materi dan software pembelajaran yang sesuai dengan mata pelajaran yang akan dibuat.

Kegiatan berikutnya berisi materi tentang "Pengenalan Karakteristik Program Pembelajaran Berbasis Komputer". Dari materi ini peserta menge- tahui ciri-ciri bahan pembelajaran berbasis komputer sebagai berikut : sistemik, jelas dan menarik, mudah digunakan, mudah diperbaiki dan mudah disebarluaskan.

Pada kegiatan terakhir pada hari pertama bertema tentang "Teknik Pembuatan Media Pembelajaran Interaktif Program Macromedia Flash". Kegiatan diawali dengan beberapa pertanyaan tentang apa itu macromedia flash, dan di dapatkan 2 guru sudah mengenal dengan baik macromedia flash dan pembuatannya, 6 guru mengenal macromedia flash tapi hanya sebatas menggunakan, 10 guru mengenal macromedia flash saja tapi tidak menggunakannya, 25 guru (58\%) tidak mengenal macromedia flash. Jadi sekitar $81 \% \quad$ (43 guru) belum dapat menggunakan macromedia flash sebagai media pembelajaran interaktif. Materi awal pada sesi ini tentang pengenalan area kerja Flash, mengenal tipe dan properties teks, memahami simbol, animasi frame by frame, animasi teks sederhana, animasi dengan mask, memasukan suara ke animasi, script sederhana penyiapan objek dan publish setting. Setelah diberikan pengenalan teori. Dari materi ini peserta memperoleh wawasan mengenai dasar-dasar pembuatan media pembelajaran berbasis Macromedia Flash. Kegiatan dilanjutkan dengan pendampingan dan pelatihan terbimbing. Peserta diminta membuat animasi sederhana untuk mengaplikasikan pengenalan teori Macromedia Flash yang telah diberikan.

Tabel 2. Tabel peningkatan pengetahuan dan keterampilan guru

\begin{tabular}{|c|c|c|c|c|}
\hline No & Uraian & $\begin{array}{l}\text { Sebe- } \\
\text { lum }\end{array}$ & $\begin{array}{l}\text { Sesud } \\
\text { ah }\end{array}$ & Target \\
\hline 1. & $\begin{array}{l}\text { Pengenalan } \\
\text { materi soft- } \\
\text { ware PBK }\end{array}$ & 29 & 43 & $\begin{array}{l}\text { Tercapai } \\
\text { (semua } \\
\text { peserta } \\
\text { mengenal } \\
\text { materi } \\
\text { software } \\
\text { PBK) }\end{array}$ \\
\hline 2. & $\begin{array}{l}\text { Pengenalan } \\
\text { materi Mac- } \\
\text { romedia flash }\end{array}$ & 8 & 43 & $\begin{array}{l}\text { Tercapai } \\
\text { (semua } \\
\text { peserta } \\
\text { menge- } \\
\text { tahui mac- } \\
\text { romedia } \\
\text { flash) }\end{array}$ \\
\hline 3. & $\begin{array}{l}\text { Demontrasi } \\
\text { program mac- }\end{array}$ & 10 & 41 & $\begin{array}{l}\text { Tercapai } \\
(95 \% \text { dari }\end{array}$ \\
\hline
\end{tabular}


romedia flash

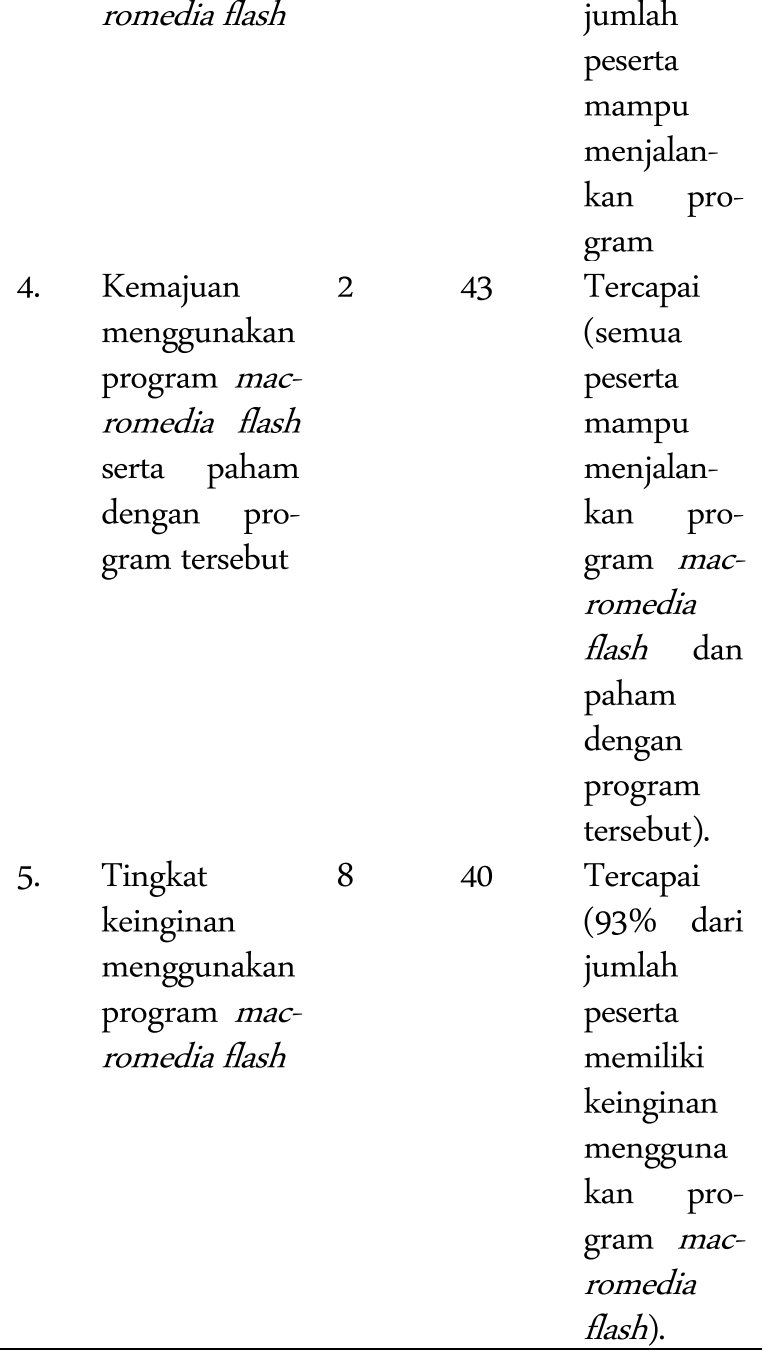

Bersamaan dengan kegiatan pelatihan terbimbing, peserta diberikan dan diperlihatkan conto-contoh media pembelajaran berbasis Macromedia Flash. Dengan harapan guru memperoleh gambaran yang jelas bagaimana hasil dari media pembelajaran yang akan dihasilkan. Selain itu, peserta diberi pemaparan mengenai tahapan-tahapan pembuatan media pembelajaran dan penyusunannya, sehingga kemudian dapat digunakan untuk menerangkan suatu konsep mata pelajaran tertentu. Dari sesi ini, peserta mampu memunculkan ide, bagaimana membuat media pembelajaran berbasis Macromedia Flash untuk memfasilitasi siswa mencapai tujuan pembelajaran terutama pada konsep-konsep yang abstrak sehingga lebih menarik. Pada saat guru diberikan demonstrasi program yang sudah dibuat pemateri hanya 10 guru (23\%) yang mampu menjalankan program yang telah dibuat sebagai sampel. Setelah diajarkan pembuatan animasi sederhana dan menjalankannya terlihat bahwa 41 guru (95\%) sudah mampu membuat animasi sederhana dari materi mata pelajaran yang mereka ampu.

Pada hari kedua, dilanjutkan dengan pelatihan mandiri. Peserta dikelompokkan berdasarkan bidang studi yang sama. Kemudian setiap kelompok diminta membuat media pembelajaran berbasis Macromedia Flash sesuai dengan mata pelajaran yang diampu oleh masing-masing guru. Pada kegiatan ini, dihasilkan produk berupa CD pembelajaran dari mata pelajaran yang diampu oleh peserta. CD pembelajaran tersebut dikumpulkan dan diberikan kepada setiap peserta untuk dijadikan sebgai alternatif media pembelajaran. CD pembelajaran ini dapat digunakan oleh guru-guru sebagai media pembelajaran yang digunakan di kelas untuk mencapai tujuan pembelajaran.

Secara keseluruhan produk dari kegiatan ini adalah: 1) Meningkatkan pengetahuan guru tentang macromedia flash., 2) Meningkatkan keterampilan guru dalam membuat media pembelajaran interaktif berbasis macromedia flash, 3) Mengaplikasikan penggunaan macromedia flash pada proses kegiatan belajar mengajar.

Beberapa faktor yang menghambat keterlaksanaan dari kegiatan ini adalah peserta belum mengenal program Macromedia Flash sehingga dibutuhkan banyak waktu untuk mengenalkan program ini dari dasar dan diberikan pendampingan secara kontinu. Sedangkan factor - faktor yang pendukung dari keterlaksanaan kegiatan ini adalah para peserta merasa senang karena metode yang digunakan selain dengan ceramah dan dialog juga dilakukan pelatihan dan pendampingan secara terbimbing dan dilanjutkan dengan pelatihan secara mandiri. Peserta dapat aktif dalam menumbuhkan kreativitasnya untuk dapat menciptakan inovasi pembelajaran.

Berdasarkan hasil analisis faktor penghambat dan pendukung dari kegiatan ini maka dapat diketahui bahwa kegiatan ini telah berjalan dengan baik, dengan indikator antusias, inovatif, dan ketersediaan alat praktek cukup memadai. Selain itu indikator dari keberhasilan ini adalah penguasaan materi, pengetahuan, dan keterampilan dalam membuat media pembelajaran berbasis Macromedia Flash untuk memfasilitasi proses pembelajaran sehingga lebih menarik dan menyenangkan.

Produk yang dihasilkan dari kegiatan ini ada $11 \mathrm{CD}$ pembelajaran dari $12 \mathrm{CD}$ pembelajaran yang diharapkan. Satu buah CD belum selesai secara menyeluruh, akan 
tetapi sudah hampir 96\% materi yang ada di dalam CD tersebut telah selesai dikerjakan oleh peserta.

Berdasarkan CD pembelajaran yang telah dibuat oleh peserta kegiatan, guru-guru telah mampu membuat $C D$ pembelajaran dengan menggunakan program Macromedia Flash. Kemampuan peserta antara lain: 1) membuat animasi tombol, 2) membuat animasi gambar, 3) menginsert suara dan musik, 4) membuka dan menyimpan file, dan 5) membuat animasi bola pantul.

\section{KESIMPULAN}

Dari hasil pelaksanaan kegiatan pengabdian kepada masyarakat tentang "Pelatihan Pembuatan Media Pembelajaran Interaktif Berbasis Macromedia Flash untuk guru-guru di SMA Perintis 1 Bandar Lampung" ini dapat dikemukakan kesimpulan sebagai berikut:

1. Peningkatan pengetahuan dan keterampilan guru dalam pembuatan media pembelajaran interaktif program macromedia flash.

2. Guru-guru SMA Perintis 1 Bandar Lampung memiliki kemampuan membuat media pembelajaran Macromedia Flash.

3. Melalui kegiatan pelatihan ini, diperoleh produk berupa $\mathrm{CD}$ pembelajaran berbasis Macromedia Flash yang dapat digunakan untuk mencapai tujuan pembelajaran dan menciptakan suasana pembelajaran yang menarik.

4. Kegiatan pelatihan ini telah memberikan bekalan kepada peserta yang tidak hanya bersifat teoritis tapi juga praktik langsung.

\section{UCAPAN TERIMA KASIH}

Penulis mengucapkan terimakasih kepada Politeknik Negeri Lampung November yang telah memberikan dukungan penuh untuk penelitian ini dari awal hingga selesai.

\section{REFERENSI}

1. Tziner A and Haccoun RR (1991) Personal and situasional charateristics influencing the effectiveness of transfer of training improvement strategies. Journal of Occupational Psychology. 64:167-177.

2. Craig, L. Shannon. 1999. Transfer training, seminar in industrial psychology. September29.(Online),(www.Geocities.com./rpipsych/transferoftrai ning.html- 31 kcached-similarpages, diakses 5 Mei 2003).
3. Atmadji, Chrisna, dan Soeleman, M. Arief. 2010. Multimedia Pembelajaran Mata Kuliah Sistem Informasi Manajemen. Jurnal Teknologi Informasi 6(1): 56-72.

4. Arsyad. A (2003) Media Pembelajaran, Edisi 4. Jakarta: Raja Grafindo Persada.

5. Hardianto D (2008) Mendesain Pembelajaran Berbasis Komputer Untuk Siswa Sekolah Dasar. Yogyakarta, FIP UNY.

6. Noe RA. \& Mondy (1996) Human resources Management, 6 ed. New York: Prentice Hall.

7. Ruriana, RE (2009) Upaya Peningkatan Aktivitas Siswa Pada Pokok Bahasan Perbandingan melalui Pendekatan Realistik (PTK Pembelajaran Matematika Kelas VII SMP Darussalam Surakarta). Skripsi. Universitas Muhammadiyah Surakarta.

8. Simamora H (1997) Manajemen sumber daya manusia, edisi ke-2, penerbit sekolah tinggi ilmu ekonomi, YKPN Yogyakarta.

9. Supardi (2005) Pelatihan pembuatan media pembelajaran interaktif berbasis macromedia flash MX untuk guru-guru fisika di daerah Istimewa Yogyakarta. Proposal.

10. Syukran (2010) Penggunaan Macromedia Flash 8 Dalam Upaya Peningkatan Kemahiran Al-Kalam Siswi Kelas IV B Madrasah Aliyah Ibnul Qoyyim Putri Tahun Ajaran 2009/2010. Skripsi. UIN Sunan Kalijaga Yogyakarta.

11. Yuniarti, Evi, Nurmala, Damayanti. 2008. Pengaruh kepercayaan teknologi sistem informasi baru terhadap peningkatan kinerja individual. Jurnal Akuntansi BisnisManajemen 15(1). 